\title{
EFFECT OF PROBLEM-BASED LEARNING MODEL AND MOTIVATION TOWARD LEARNING OUTCOMES ON NETWORK ROUTING
}

\author{
Kurnia Dwi Ariyanti1 ${ }^{1}$, Aye Aye $\mathrm{Mon}^{2}$, Ekohariadi $^{3}$, and Lilik Anifah ${ }^{4}$ \\ ${ }^{134}$ Universitas Negeri Surabaya, Surabaya, Indonesia \\ ${ }^{2}$ Department of Mechanical Engineering Department Technical Promotion Training Centre, Baelin, Myanmar \\ E-mail: kurniaariyanti@mhs.unesa.ac.id
}

\begin{abstract}
This study explored the effect of problem-based learning and motivation toward learning outcomes of the subject of computer routing network. Computer routing network is part of the subject of computer network design in a computer network engineering class. The purpose of this study was to examine the difference in learning outcomes between students treated with the problems based learning model and treated with direct learning model by considering students' learning motivation. This study was categorized as quasi-experimental designed with a factorial experimental design. The sampling technique used purpose-sampling. The data were analyzed using a two-way Anava method. The results of the study showed that (1) the learning outcomes of students in the subject of routing network with problem-based learning model was better than the student treated with direct instruction learning, (2) based on the learning outcomes in the subject of routing network, a group of students with high motivation was better, and (3) there is an interaction between the application of problembased-learning model and motivation to the students learning outcomes.
\end{abstract}

Keywords: direct instruction, learning motivation, problem based learning

\section{INTRODUCTION}

Learning is the process of interaction between learners, between learners with educators and learning resources in a learning environment. The learning process of the educational unit is organized in an interactive, inspiring, fun, challenging, motivational way for active participation, and provides sufficient space for initiative, creativity, and independence according to the talents, interests, and physical and psychological development of learners [1].

Vocational education should provide sufficient theories, practice, and examples of real problem solving by utilizing learning models, learning strategies, learning methods, and learning media that support the learning process in the aspects of cognitive, affective, and psychomotor, and develop social, emotional, spiritual, and so on. Slameto [2] suggests that learning is influenced by two factors, internal factors, and external factors. Internal factors are factors that come from within the individual for example of intention, achievement motivation, attitude, motivation to learn. While the external factor is a factor comes from outside the individual for example learning model. One of the learning models is problem-based learning (PBL) which is a learning model that teaches students to solve problems and improve their knowledge.

Routing network is a part of the subject computer network design that is a mechanism of transfer information from source to destination through a network. Network routing occurs on the Open System Interconnection (OSI) in network layer that is implemented within a router. Routers function as a network link with each other by sending data packets from source to destination by doing the previous routing process. The routing process is done by building the routing table, and the router is very dependent on the routing used. This routing used as a rule in the routing process commonly referred to as a routing protocol. There are three types of routing: default routing, static routing and dynamic routing [3]. A troubleshooting process needed to determine which routing table effective in data transfer efficiency. In the learning process of the routing network founded a variety of 
problems such as the lack of network devices to conduct experiments network design and the difficulty of applying the type of network routing. The amount of equipment used in network experiments is very limited in number compared to the number of students. The students' achievement did not meet the minimum criteria of mastery learning of this subject. Previous learning activities used to teach declarative knowledge, and procedural knowledge is direct instruction.

Criticisms of the direct instruction model are that it cannot be used at any time and not for all learning purposes and not for all students, emphasized on the teacher's lecture. In addition, the direct instruction model is limited to teaching basic skills and low-level information, so the learning direct instruction model is not suitable for achieving high-level goals. In addition, the direct instruction model sees students just like empty vessels filled with bits of information rather than being active learners. The students are given less the opportunity to explore the potential within them [4].

Prabowo [5] concludes that the students' learning outcomes with the problem-based learning (PBL) model are better than learning outcomes using the direct instruction model. Rohani \& Sahar [6] also conclude problembased learning (PBL) as a new approach with significant influence on student performance. According to Jalani \& Lai [7], problem-based learning $(\mathrm{PBL})$ is a learning model that leads to better performance test results. Elaine \& Karen [8] concluded problem-based learning (PBL) an effective learning model especially when it is evaluated and applied in a long time.

In addition to the using of appropriate learning models, in a learning process is a motivation required as an internal factor to improve students' learning outcomes. Motivation to learn is one form of activeness of a person encourages to conduct a series of soul and body activities to obtain a change in behavior as a result of individual experience in interactions in the environment involves cognitive, affective and psychomotor. In addition, the motivation to learn is the overall driving force in the students to leads the learning activities, which ensures the continuity of the learning activities and gives direction to the learning activities, so that the desired goal by the study subject can be achieved [9].

Considering the complexity, characteristic and importance of routing network, and the result of direct instruction process, the learning result obtained by students is only in the form of verbal information, less leads to the effort of improving the skill and attitude of the students, this matter can cause the low motivation of student learning in following the learning activity of routing networks, and results in low student learning outcomes on this subject. Based on these conditions, it attracts to research in order to solve existing problems and to improve learning outcomes both from the aspect of cognitive, affective aspects and psychomotor aspects compare to the direct instruction model.

In addition to the use of appropriate learning models, learning motivation is also needed to improve student learning outcomes. The essence of learning motivation an internal and external impulse to students learning to make behavioral changes in one's success in learning. Motivation to learn has a very important role because its existence is very meaningful for the act of learning and as the director for learning actions to the clear goals expected to be achieved [10].

Learning media used is CISCO packet tracer which is simulation software to help students to design and simulate computer network, computer network configuration, simulation of routing, routing configuration, discovery, decision making, creative thinking, critical, and assist in solving computer network problem. According to the Cisco packet tracer data sheet, the Cisco packet tracer is a network simulation tool designed to facilitate the world of education in order to facilitate the learning process of network technology and also can use to help students or teachers in doing experiments on building a computer network. 
Based on these advantages, it is expected the students' learning outcomes who follow the learning with the problem-based learning model using cisco packet tracer as a better medium when compared with students follow the learning direct instruction model consider of student's motivation.

The purpose of this study is to examine (1) learning outcomes in the subject of routing network between students treated with problem based learning model and students treated with direct instruction learning, (2) the differences of learning outcomes in routing-network between groups have high and low motivation, and (3) interaction between the application of problembased-learning model and motivation to the students' learning outcomes.

\section{METHOD}

This study is a quasi-experimental study with a factorial experimental design. The factorial design modification of the true experimental design, by considering the possibility of a moderator variable affecting the treatment (independent variable) on the result (dependent variable) [11]. The design factorial paradigm adapted from Sugiyono [11] is illustrated in Figure 1.

The population of this study consisted of the students of class XI in the Department of Computer Network Engineering, SMK N 1 Trowulan. Interpretation of the sample used a purposive sampling technique. The purposesampling technique is the technique of determining the sample with certain considerations. Based on the description, class XI TKJ 1 was selected as the control group and class XI TKJ 2 as the experimental group. In this design, there were two groups used as research subjects, the experiment group and the control group. The experiment group class was given a lesson using the problem-based learning model while the control group used the direct instruction model. The moderator variable that influences the treatment is the students' learning motivation divided into high learning

motivation and low learning motivation. The design of this study is shown in Table 1.

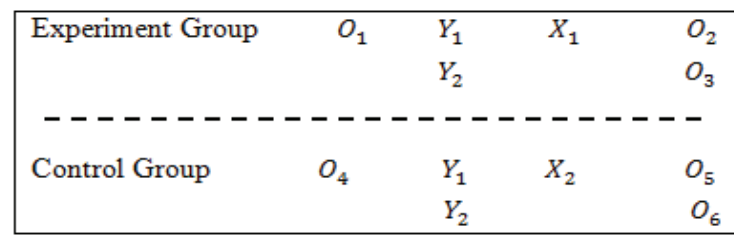

Figure 1. Research Design

Where

$O_{1} \quad$ : $\quad$ The pretest result of the experiment group

$O_{4} \quad$ : $\quad$ The pretest result of the control group

$X_{1} \quad$ : Treatment using the problem-based learning model

$X_{2} \quad$ : $\quad$ Treatment using the direct instruction model

$Y_{1} \quad: \quad$ High motivation

$Y_{2} \quad: \quad$ Low motivation

$\mathrm{O}_{2} \quad$ : $\quad$ The posttest result in high-motivated students of the experiment group

$\mathrm{O}_{3} \quad$ : $\quad$ The posttest result in low-motivated students of the experiment group

$O_{5} \quad: \quad$ The posttest result in high-motivated students of the control group

$O_{6} \quad: \quad$ The posttest result in low-motivated students of the control group

Table 1. Research Design

\begin{tabular}{|c|c|c|c|}
\hline \multirow{2}{*}{\multicolumn{2}{|c|}{ Motivation }} & \multicolumn{2}{|c|}{ Learning Model } \\
\hline & & $\operatorname{PBL}\left(\mathrm{X}_{1}\right)$ & $\operatorname{MPL}\left(\mathrm{X}_{2}\right)$ \\
\hline \multicolumn{2}{|c|}{ High-motivation ( $\left.\mathrm{Y}_{1}\right)$} & $\mathrm{X}_{1} \mathrm{Y}_{1}$ & $\mathrm{X}_{2} \mathrm{Y}_{1}$ \\
\hline \multicolumn{2}{|c|}{ Low-motivation $\left(\mathrm{Y}_{2}\right)$} & $\mathrm{X}_{1} \mathrm{Y}_{2}$ & $\mathrm{X}_{2} \mathrm{Y}_{2}$ \\
\hline \multicolumn{4}{|l|}{ Where } \\
\hline $\mathrm{X}_{1} \mathrm{Y}_{1}$ & \multicolumn{3}{|c|}{$\begin{array}{l}\text { Students' learning outcomes using the } \\
\text { problem-based learning model at } \\
\text { students with high learning motivation }\end{array}$} \\
\hline $\mathrm{X}_{2} \mathrm{Y}_{1}$ & \multicolumn{3}{|c|}{$\begin{array}{l}\text { Student learning outcomes using the } \\
\text { direct learning model for students with } \\
\text { high learning motivation }\end{array}$} \\
\hline $\mathrm{X}_{1} \mathrm{Y}_{2}$ & \multicolumn{3}{|c|}{$\begin{array}{l}\text { Students' learning outcomes using the } \\
\text { problem-based learning model for } \\
\text { students with low learning motivation }\end{array}$} \\
\hline $\mathrm{X}_{2} \mathrm{Y}_{2}$ & \multicolumn{3}{|c|}{$\begin{array}{l}\text { Students' learning outcomes using } \\
\text { direct learning model at students with } \\
\text { low learning motivation }\end{array}$} \\
\hline
\end{tabular}

The research variables consists of (1) independent variable of learning method; (2) moderator variable of learning motivation; (3) control variable with same material, same teacher, same allocation of time and same learning resources; and (4) the dependent variable of students' learning results on computer network routing material in the aspects of cognitive, affective, and psychomotor domains. 
The data collection used the method of tests and observation. The tests in this study were used to measure learning outcomes in the experiment group and the control group before and after the treatment. The tests were given to both classes which included pre-test and posttest tests. Tests used were in the form of multiple choice questions that had been tested first to qualify the validity and reliability. The questionnaire consists of 40 questions related to computer network routing. The results of the pretest were used to measure the initial ability of students before the treatment, while the result of the post-test was used to examine the result of the study after the treatment. Meanwhile, the observation method was used to observe students' learning outcomes based on the psychomotor domain and affective domain. The motivation to learn was analyzed using a questionnaire to classify students with high motivation and low motivation.

After all, data collected, test prerequirement must be done to determine whether the data used is parametric data and nonparametric data. Test pre-requirements analysis included a normality test and a homogeneity test. The normality test and the homogeneity test used a Kolmogorov-Smirnov test and a Levene-test respectively. If the data is normal and homogeneous, then they will proceed further with hypothesis testing. Hypothesis testing used Analysis of Variance (two-way Anava).

\section{RESULTS AND DISCUSSION}

Before performing the hypothesis, testing, a pre-requisite test should be firstly performed (normality and homogeneity test) on student' learning outcomes. With a significance level of $\alpha=0.05$, data can be categorized as a normal distribution (normal test) and homogeneity (homogeneity test) if sig $>0.05$ and data is not normal and not homogeneous distribution if $\operatorname{sig}<0.05$. The normality test used a Kolmogorov-Smirnov test. The results of the normality test of learning results in the cognitive domain, affective domain and psychomotor domain in the experiment group and the control group can be seen in Table 2 and Table 3 respectively. The normality test of learning results from both groups has a significance value $>0.05$. It means the data from both groups had a normal distribution.

Table 2. The Normality Test of Learning Results in the Experiment Group

\begin{tabular}{llccc}
\hline & Motivation & \multicolumn{3}{c}{ Kolmogorov-Smirnov } \\
& & Statistic & df & Sig. \\
\hline \multirow{2}{*}{ Cognitive domain } & High & .144 & 21 & $.200^{*}$ \\
& Low & .235 & 7 & $.200^{*}$ \\
Affective domain & High & .120 & 21 & $.200^{*}$ \\
& Low & .246 & 7 & $.200^{*}$ \\
Psychomotor & High & .141 & 21 & $.200^{*}$ \\
domain & Low & .267 & 7 & .142 \\
\hline
\end{tabular}

Table 3. The Normality Test of Learning Results in the Control Group

\begin{tabular}{lcccc}
\hline & Motivation & \multicolumn{3}{c}{ Kolmogorov-Smirnov ${ }^{\mathrm{a}}$} \\
\cline { 3 - 5 } & & Statistic & df & Sig. \\
\hline \multirow{2}{*}{ Cognitive domain } & High & .168 & 17 & $.200^{*}$ \\
& Low & .178 & 11 & $.200^{*}$ \\
\multirow{3}{*}{ Affective domain } & High & .174 & 17 & .182 \\
& Low & .202 & 11 & $.200^{*}$ \\
Psychomotor & High & .195 & 17 & .087 \\
domain & Low & .223 & 11 & .133 \\
\hline
\end{tabular}

The homogeneity test of learning results in the experiment class and the control class is used to know the variance of both classes is the same or not. To test the similarity of variance, it was used a Levene's Test. Homogeneity test results can be seen in Table 4, Table 5, Table 6, and Table 7.

Table 4. The Homogeneity Test of Learning Outcomes in the Experiment and Control Classes with High Motivation

\begin{tabular}{|c|c|c|c|c|}
\hline & $\begin{array}{l}\text { Levene } \\
\text { Statistic }\end{array}$ & df1 & $\mathrm{df} 2$ & Sig. \\
\hline $\begin{array}{l}\text { Cognitive Scores of high } \\
\text { motivation groups in the } \\
\text { experiment and control classes }\end{array}$ & .757 & 1 & 36 & .390 \\
\hline $\begin{array}{l}\text { Affective Scores of high } \\
\text { motivation groups of the } \\
\text { experimental and control classes }\end{array}$ & .009 & 1 & 36 & .926 \\
\hline $\begin{array}{l}\text { Psychomotor Scores of high } \\
\text { motivation groups of the } \\
\text { experimental and control classes }\end{array}$ & 1.256 & 1 & 36 & .270 \\
\hline
\end{tabular}


Table 5. The Homogeneity Test of Learning Outcomes in the Experiment Class with High Motivation and the Control Class with Low Motivation

\begin{tabular}{|c|c|c|c|c|}
\hline & $\begin{array}{l}\text { Levene } \\
\text { Statistic }\end{array}$ & df1 & df2 & Sig. \\
\hline $\begin{array}{l}\text { Cognitive Scores of High } \\
\text { Motivation Group of } \\
\text { Experiment class and Low } \\
\text { Motivation group of Control } \\
\text { Class }\end{array}$ & .826 & 1 & 30 & .371 \\
\hline $\begin{array}{l}\text { Affective Scores of High } \\
\text { Motivation Group of } \\
\text { Experiment class and Low } \\
\text { Motivation group of Control } \\
\text { Class }\end{array}$ & .721 & 1 & 30 & .403 \\
\hline $\begin{array}{l}\text { Psychomotor Scores of High } \\
\text { Motivation Group of } \\
\text { Experiment class and Low } \\
\text { Motivation group of Control } \\
\text { Class }\end{array}$ & 200 & 1 & 30 & .658 \\
\hline
\end{tabular}

Table 6. The Homogeneity Test of Learning Outcomes in the Experiment Class with Low Motivation and the Control Class with High Motivation

\begin{tabular}{|c|c|c|c|c|}
\hline & $\begin{array}{l}\text { Levene } \\
\text { Statistic }\end{array}$ & df1 & df2 & Sig. \\
\hline $\begin{array}{l}\text { Cognitive Scores of the low } \\
\text { Motivation Group of the } \\
\text { Experiment class and High } \\
\text { Motivation group of the } \\
\text { Control Class }\end{array}$ & 2.279 & 1 & 22 & .147 \\
\hline $\begin{array}{l}\text { Affective Scores of the Low } \\
\text { Motivation Group of } \\
\text { Experiment class and the } \\
\text { High Motivation group of } \\
\text { the Control Class }\end{array}$ & .728 & 1 & 22 & .403 \\
\hline $\begin{array}{l}\text { Psychomotor Scores of Low } \\
\text { Motivation Group of the } \\
\text { Experiment class and the } \\
\text { High Motivation group of } \\
\text { the Control Class }\end{array}$ & .094 & 1 & 22 & .762 \\
\hline
\end{tabular}

Table 7. The Homogeneity Test of Learning Outcomes in the Experiment and the Control Classes with Low Motivation

\begin{tabular}{|c|c|c|c|c|}
\hline & $\begin{array}{l}\text { Levene } \\
\text { Statistic }\end{array}$ & dfl & df2 & Sig. \\
\hline $\begin{array}{l}\text { Cognitive Scores of the low } \\
\text { Motivation Groups in the } \\
\text { Experiment and Control } \\
\text { Classes }\end{array}$ & 2.851 & 1 & 16 & .111 \\
\hline $\begin{array}{l}\text { Affective Scores of the low } \\
\text { Motivation Groups in the } \\
\text { Experiment and Control } \\
\text { Classes }\end{array}$ & 4.137 & 1 & 16 & .059 \\
\hline $\begin{array}{l}\text { Psychomotor Scores of the } \\
\text { low Motivation Groups in } \\
\text { the Experiment and Control } \\
\text { Classes }\end{array}$ & 1.169 & 1 & 16 & .296 \\
\hline
\end{tabular}

The analysis of the prerequisite test shows the data has been qualified for further tested by testing the hypothesis. Testing the value of statistical hypotheses is the last step used to decide whether the answer from the formulation of the problem mentioned on the research hypothesis is true or false, in other words, the statistical hypothesis test also means whether the hypothesis can be accepted or rejected. In this study, a separated of statistical hypothesis test was conducted between cognitive domain learning results, effective learning results, and psychomotor domain learning results to students' learning motivation. The statistical hypothesis test used in the study was a two-way Anava. The results are shown in Table 8, Table 9, and Table 10. Then to answer the research hypothesis, the basic decision-making is If significant value $>$ 0.05 then $\mathrm{H}_{0}$ is accepted and If significant value $<0.05$ then $\mathrm{H}_{0}$ is rejected or received $\mathrm{H}_{\mathrm{a}}$

Table 8. Statistical Hypothesis Test Results of the Cognitive Domain

\begin{tabular}{lccc}
\hline Source & F & Sig. & Value \\
\hline Motivation & 6.402 & .014 & $<0.05$ \\
Learning Model & 7.523 & .008 & $<0.05$ \\
Motivation * Learning & 10.470 & .002 & $<0.05$ \\
Model & & & \\
\hline
\end{tabular}

Table 9. Statistical Hypothesis Test Results of the Affective Domain

\begin{tabular}{lccc}
\hline Source & F & Sig. & Value \\
\hline Motivation & 15.689 & .000 & $<0.05$ \\
Learning Model & 7.631 & .008 & $<0.05$ \\
Motivation * Learning & 8.389 & .006 & $<0.05$ \\
Model & & &
\end{tabular}

Table 10. Statistical Hypothesis Test Results of the Psychomotor Domain

\begin{tabular}{lccc}
\hline Source & F & Sig. & Value \\
\hline Motivation & 13.995 & .000 & $<0.05$ \\
Learning Model & 6.039 & .017 & $<0.05$ \\
Motivation * Learning & 8.047 & .006 & $<0.05$ \\
Model & & & \\
\hline
\end{tabular}

Table 11 explains the learning outcomes of the students treated with the problem-based learning model show better learning outcomes in the domains of cognitive, affective and 
psychomotor than students treated with the direct learning model.

Table 11. Summary of Mean of Students' Learning Outcomes

\begin{tabular}{lccc}
\hline \multirow{2}{*}{$\begin{array}{l}\text { Learning } \\
\text { Model }\end{array}$} & \multicolumn{3}{c}{ Mean } \\
\cline { 2 - 4 } & Cognitive & Affective & Psychomotor \\
\hline $\begin{array}{l}\text { Problem Based } \\
\text { Learning }\end{array}$ & 86.488 & 86.641 & 85.169 \\
Direct Interaction & 82.694 & 83.657 & 82.019 \\
\hline
\end{tabular}

Different results of students' learning are influenced by the role of students in the learning process. In the experimental class through the problem-based model, the students are more active in the learning process so the students' understanding of the subject is higher and students' skills development is better. The teacher divides the students into groups, and each group member has the responsibility to focus on the learning materials to be solved. Through this way, students can develop knowledge, communication skills, and skills in solving every problem. In this learning model, students learn through problem-solving and reflect on their experiences.

Gabriel et al. [12] problem-based learning (PBL) uses real problem context for students to think critically about solving a problem. It emphasizes communication between teachers and students. Students are required to be active in the learning process, while the teacher received feedback from the students and control in accordance with the existing problems. While the direct learning model cannot be used at all times and not for all learning purposes and not for all students. This learning model is emphasized in teachers' lectures. The view of the direct learning model is to look at students like empty vessels filled with bits of information rather than being active learners, fewer students being given the opportunity to explore the potential within them [4].

Studies from previous studies also show similar results. Prabowo [5] concluded students' learning outcomes with the problem-based learning model is better than learning outcomes using the direct learning model. Rohani \& Sahar [6] concluded problem-based learning as a new approach that has a significant influence on students' performance. According to Jalani \& Lai [7], problem-based learning (PBL) is a lead model to better performance test results. Elaine \& Karen [8] concluded problem-based learning (PBL) as an effective learning model especially when it is evaluated and applied in the long term. Ahmet et al. [13] concluded that students treated with problem-based learning (PBL) have higher scores.

PBL helps students to improve their thinking process skills, and also students have a positive perception of problem-based learning. Ersoy \& Baser [14] concluded that PBL has contributed to the development of students' creative thinking skills rather than using traditional teaching methods. Gurses et al. [13] also concluded that at the end of the application of the problem-based learning model there was a significant difference in students' achievement between the pre-test and the posttest. Aweke et al. [15] concluded that there were significant differences in learning outcomes between the groups given learning models problem-based learning (PBL) and groups not given problem-based learning (PBL). Table 12 explains that students' learning outcomes with high learning motivation show significantly higher outcomes than student learning outcomes with low learning motivation.

Table 12. Mean Scores of Students' Learning Outcomes on Motivational Influences

\begin{tabular}{cccc}
\hline \multirow{2}{*}{ Motivation } & \multicolumn{3}{c}{ Mean } \\
& Cognitive & Affective & Psychomotor \\
\hline High & 86.341 & 87.288 & 85.991 \\
Low & 82.841 & 83.009 & 81.196 \\
\hline
\end{tabular}

Learning motivation is the overall driving force within the students to lead the learning activities, which ensures the continuity of learning activities and gives direction to learning activities, so the desired goal by the study subject can be achieved [9]. Motivation has three functions namely (1) encouraging 
people to do, as a motor that releases energy, (2) determine the direction of action, towards the goal to be achieved, and (3) selecting the work to be complete in harmony to achieve the goal, by setting aside actions are not beneficial to the purpose. Garner et al. in Nur [4] stated that students who are motivated to learn something would use a higher cognitive process in learning the materials, so students will absorb and precipitate the materials better.

In the opinion of the experts above, it can be concluded motivation is one of the most important elements of effective teaching or successful teaching. Which is the impetus for using higher cognitive processes in learning the materials, so the students will absorb and precipitate the subject better so the learning objectives will be achieved well. In learning activities of students with high learning motivation to obtain higher learning outcomes than students learn with low learning motivation because students with high motivation to learn are more excited, diligent and resistant in learning so they will be easier in processing information obtained and the students will find it easier to solve the problems thus the learning outcomes are significantly higher. As shown in Table 12, the average score of students with high motivation is greater than those with low motivation. Table 13 explains the interaction relationships that influence each other between the learning model and the learning motivation of the learning outcomes.

Table 13. Summary of Mean Interaction of Students' Learning Outcomes

\begin{tabular}{|c|c|c|c|c|}
\hline & Motivation & $\begin{array}{l}\text { Problem } \\
\text { Based } \\
\text { Learning } \\
\text { (PBL) }\end{array}$ & $\begin{array}{c}\text { Direct } \\
\text { Interactio } \\
\text { n (DI) }\end{array}$ & Explanation \\
\hline \multirow[t]{2}{*}{ Cognitive } & High & 82.500 & 83.182 & $\mathrm{PBL}<\mathrm{DI}$ \\
\hline & Low & 90.476 & 82.206 & $\mathrm{PBL}>\mathrm{DI}$ \\
\hline \multirow[t]{2}{*}{ Affective } & High & 82.937 & 83.082 & $\mathrm{PBL}<\mathrm{DI}$ \\
\hline & Low & 90.344 & 84.232 & $\mathrm{PBL}>\mathrm{DI}$ \\
\hline \multirow[t]{2}{*}{ Psychomotor } & High & 80.953 & 81.439 & PBL $<$ DI \\
\hline & Low & 89.384 & 82.598 & $\mathrm{PBL}>\mathrm{DI}$ \\
\hline
\end{tabular}

Learning model and students' learning motivation influence the students' learning results. Students using the problem-based learning model and or the direct learning model will tend to increase if students have high learning motivation compared to students with low learning motivation. Therefore the learning model and learning motivation have reciprocal interaction as a factor in influencing one and each other to reach students' learning outcomes. This study showed problem-based learning (PBL) is very effective for students with high learning motivation while direct interaction learning is very effective for students with low learning motivation. Therefore the combination of the learning model and students' learning motivation is influencing one and each other and also has an effect on one another.

\section{CONCLUSION}

This study showed that the students treated with the problem-based learning model at computer network routing items have a better result than students with the learning direct interaction learning model. PBL is very effective to be used by students with high learning motivation while the direct interaction learning model is effective for students with low motivation. Based on the results of hypothesis testing, the PBL model demonstrates significantly higher learning outcomes than the direct interaction learning model does. In addition, learning motivation significantly prompts students' learning outcomes. There is interaction among applied learning with students' learning motivation to students' learning outcomes.

\section{REFERENCES}

[1] Ministry of National Education, Peraturan Pemerintah (PP.) No. 32 Tahun 2013.tentang Standar Nasional Pendidikan, Pasal 19. Ministry of National Education, 2013.

[2] Slameto, Belajar dan Faktor-faktor yang 
Mempengaruhinya. Jakarta: Rineka Cipta, 2010.

[3] Stalling and William, Data and Computer Communications.1st Edition. New Jersey: Prentice Hall, Inc, 2008.

[4] M. Nur, "Pandangan Belajar dan Pembelajaran Konstruktivis," Universitas Negeri Surabaya, 2008.

[5] C. T. Prabowo, "Pengaruh Metode Pembelajaran Project Based Learning Terhadap Prestasi Belajar Siswa Mata Pelajaran Las Lanjut Kelas XI Jurusan Teknik Pemesinan SMK Muhammadiyah Prambanan," Universitas Negeri Yogyakarta, 2015.

[6] R. A. Tarmizi and S. Bayat, "Collaborative Problem-Based Learning in Mathematics: A Cognitive Load Perspective," Procedia-Social Behav. Sci., vol. 32, pp. 344-350, 2012.

[7] N. H. Jalani and L. C. Sern, "Efficiency Comparisons Between ExampleProblem-Based Learning and TeacherCentered Learning in the Teaching of Circuit Theory," Procedia - Soc. Behav. Sci., vol. 204, pp. 153-163, 2015.

[8] E. H. J. Yew and K. Goh, "ProblemBased Learning: An Overview of its Process and Impact on Learning," Heal. Prof. Educ., vol. 2, no. 2, pp. 75-79, 2016.

[9] A. M. Sardiman, Interaksi dan Motivasi Belajar Mengajar. Jakarta: Rajawali, 1986.
[10] Hamzah B Uno, Teori Motivasi dan Pengukurannya. Jakarta: Bumi Aksara, 2014.

[11] Sugiyono, Metodelogi Penelitian Pendidikan. Bandung: Alfabeta, 2016.

[12] G. Gorghiu, L. M. Drăghicescu, S. Cristea, A.-M. Petrescu, and L. M. Gorghiu, "Problem-based Learning - An Efficient Learning Strategy in the Science Lessons Context," Procedia Soc. Behav. Sci., vol. 191, pp. 18651870, Jun. 2015.

[13] A. Gurses, C. Dogar, and E. Geyik, "Teaching of the Concept of Enthalpy Using Problem Based Learning Approach," Procedia - Soc. Behav. Sci., vol. 197, pp. 2390-2394, Jul. 2015.

[14] E. Ersoy and N. Baser, "The Effects of Problem-Based Learning Method in Higher Education on Creative Thinking," Procedia-Social Behav. Sci., vol. 116, pp. 3494-3498, 2014.

[15] A. S. Argaw, B. B. Haile, B. T. Ayalew, and S. G. Kuma, "The Effect of Problem Based Learning (PBL) Instruction on Students' Motivation and Problem Solving Skills of Physics," Eurasia J. Math. Sci. Technol. Educ., vol. 13, no. 3, pp. 857-871, 2017. 